\title{
Vulnerability study of a two-story reinforced concrete school building structure in Banda Aceh toward earthquakes and tsunami hazards
}

\author{
Sausan Zahrah ${ }^{1 *}$ and Muhammad Fawzul Aziim Afif ${ }^{3}$ \\ ${ }^{1}$ Student of Civil Engineering Department, Postgraduate Program, Syiah Kuala University, Jl. Syeh Abdurrauf No. 7, Banda Aceh, \\ 23111, Indonesia \\ ${ }^{2}$ Former Student of Civil Engineering Department, Faculty of Engineering, Syiah Kuala University, Jl. Syeh Abdurrauf No. 7, Banda \\ Aceh, 23111, Indonesia
}

\begin{abstract}
Banda Aceh city is an earthquake-prone area. One is the phenomenon that a magnitude $9,3 \mathrm{M}_{\mathrm{w}}$ and subsequent tsunami wave occurred in 2004. The incident caused casualties and damage to facilities including educational facilities such as school buildings. After the 2004 Tsunami, affected school was rebuilt insame location as before, therefore necessary to conduct an assessment of school building to ensure safety and comfort of learning process in affected area. The purpose of this study was to determine structure capacity of reinforced concrete school building structure toward earthquake and Tsunami in Banda Aceh, so it can see contruction vulnerability based on table of damage state. Objects in this study was a typical two-story reinforced concrete school buildings in Banda Aceh. The chosen building were SDN 48 and SDN 8. Structures were modelled by using SAP2000 software. Earthquake load data using the2004 SumateraAndaman earthquake and Puskim earthquake-predictions which were analyzed using pushover method, and tsunami loads based on the height of inundation at location of school building. As a results, it has been developed capacity curve and spectrum capacity curve to determine damage limit and probability due to earthquake and tsunami hazards. It was found that based on spectrum capacity curve bothschool buildings in slight damage, while based on fragility curve it was found that both school building havea risk of light damage and moderate damage. Based on tsunami load, it has been found that both school building has inter-story drift that exceeds allowable limit, and based on tsunami fragility curve both schoolbuilding were predicted complete damage.
\end{abstract}

\section{Introduction}

Banda Aceh city is an earthquake-prone area. This is because Banda Aceh City is located between two fault segments, namely the Aceh fault segment and the Seulimuem fault segment that still active [1]. A large Earthquake has occurred in Banda Aceh with 9,3 $\mathrm{M}_{\mathrm{w}}$ and followed by tsunami wave that devastated the city and its surroundings in 2004. The hazards caused significant loss of life and damage to buildings. The loss of life and damage to facilities that occurred in this disaster was quite significant, one of them was in education sector. After the 2004 Tsunami, schools were rebuilt in their former locations, so to ensure the safety and comfort of school buildings in the affected areas, it was necessary to conduct a vulnerability assessment of the building. The purpose of this study was to determine structure capacity of two-story reinforced concrete school building structure toward earthquake and Tsunamis in Banda Aceh. As an object in this study was a typical two-story reinforced concrete school building structure that are mostly found in the Banda Aceh city. In general, the typical structure of a school building in Banda Aceh city is a two-story reinforced concrete construction. Earthquake calculation method was used the pushover analysis method; it was used to see the fragility curve. Fragility curve is a curve that shows how much the possibility of building vulnerability when the earthquake occurred [2]. The fragility curve will show the probability of damage to the building structure with various damage conditions, namely slight damage, moderate damage, extensive damage and complete damage. In addition to calculating the earthquake, tsunami load calculations are also needed in the structural design of the building so as to reduce the risk of damage to the building structure during the earthquake and tsunami. Therefore, this study was conducted to determine whether wo-story reinforced concrete school building structure have meet the existing regulatory standards or not. So from this study can see the vulnerability that occurs for typical reinforced concrete school building to be reviewed in the region of Banda Aceh as well as immediate recommendations for improvements and efforts to improve the structure in order to reduce the risk of. The result of this research is the determination of damage states in SDN 48 and SDN 8 buildings obtained from the spectrum capacity curve is in the position of slight

\footnotetext{
* Sausan Zahrah: szahrah02@gmail.com
} 
damage or light damage, while based on the fragility curve that has been developed the school buildings have a risk of light damage and moderate damage. In the calculation due to the tsunami load, the school building has an inter-story drift that exceeds allowable limit and based on tsunami fragility curve that has been developed, SDN 48 and SDN 8 buildings are predicted to be complete damage.

\section{Literatur review}

\subsection{Parameters design of response spectra}

According to SNI 1726:2019[3], response spectrum is a spectrum that is presented in the form of a graph or plot that describes the relationship between the maximum response acceleration of a system of one degree of freedom due to a particular earthquake, as a function of the damping factor and natural vibration time.

\subsection{Limitation of fundamental periodic structures}

Based on SNI 1726:2019[3], the fundamental period should not exceed the coefficient result for the calculated period limitation $(\mathrm{Cu})$ according to Appendix Table B.7 and the approximate fundamental period (Ta). As an alternative to carrying out the analysis to determine the fundamental period of the structure $(T)$ it is permitted to directly use the approximate building period $(\mathrm{Ta})$ and is determined from the following equation:

$$
T_{\mathrm{a}}=C_{\mathrm{t}} \cdot h_{\mathrm{n}}^{\mathrm{x}}
$$

\subsection{Tsunami}

Tsunami waves cannot be seen when they are far in the middle of the ocean, but once they reach shallow areas the waves will move quickly. Energy from the tsunami is still a function of the height and so on [4]. The energy forms the forces that will become a burden on the building structure.

\subsection{Structure behavior}

Structural behavior is a behavior caused by the building due to the force. This behavior includes moving and moving between floors. displacement is the deviation of a floor measured from the ground floor, while interstory drift is the horizontal displacement at the top of the level under consideration relative to the bottom. Dimana the inter-story drift permit level $\left(\Delta_{\mathrm{a}}\right)$ can be seen in the following table:

\subsection{Capacity curve and spectrum capacity curve}

In the study by Utomo, et al [5], in addition to showing structure behaviour on the condition of elastic, plastic and up to the collapse, pushover analysis can also produce an overview of the relationship between the base shear and the roof structure or roof displacement, this relationship is then mapped as a capacity curve. In the pushover process, the structure is pushed until it yields at one or more locations in the structure. The capacity curve will show a linear condition before reaching the melting state and after that it behaves nonlinearly. While the spectrum capacity curve is the relationship between spectral acceleration $(\mathrm{Sa})$ to spectral displacement $(\mathrm{Sd})$, to get the spectrum capacity curve, the capacity curve needs to be changed to a spectrum capacity curve.

Table 1. Inter-story drift permit level.

\begin{tabular}{|c|c|c|c|}
\hline \multirow{2}{*}{ Structure } & \multicolumn{3}{|c|}{ Risk category } \\
\hline & I / II & III & IV \\
\hline $\begin{array}{l}\text { Structures, other than brick shear } \\
\text { wall structures, } 4 \text { stories or less } \\
\text { with interior walls, partitions, } \\
\text { ceilings and exterior wall } \\
\text { systems designed deviations } \\
\text { accommodate } \\
\text { between stories. }\end{array}$ & $\begin{array}{c}0,025 \\
h_{s x}{ }^{c}\end{array}$ & $\begin{array}{l}0,02 \\
0 h_{s x}\end{array}$ & $\begin{array}{c}0,015 \\
h_{s x}\end{array}$ \\
\hline $\begin{array}{l}\text { Brick cantilever shear wall } \\
\text { structure }\end{array}$ & $\begin{array}{l}0,010 \\
h_{s x}\end{array}$ & $\begin{array}{l}0,01 \\
0 h_{s x}\end{array}$ & $\begin{array}{l}0,010 \\
h_{s x}\end{array}$ \\
\hline Other brick shear wall structures & $\begin{array}{l}0,007 \\
h_{s x}\end{array}$ & $\begin{array}{l}0,00 \\
7 h_{s x}\end{array}$ & $\begin{array}{l}0,007 \\
h_{s x}\end{array}$ \\
\hline All other structures & $\begin{array}{l}0,020 \\
h_{s x}\end{array}$ & $\begin{array}{l}0,01 \\
5 h_{s x}\end{array}$ & $\begin{array}{l}0,010 \\
h_{s x}\end{array}$ \\
\hline
\end{tabular}

Source: SNI 1726:2019 [3]

\subsection{Seismic fragility curve and tsunami fragility curve}

According to Wibowo [6], Seismic fragility curve is a curve that shows the possibility of damage that occurs to a structure when it receives an earthquake load with a certain intensity. From the research of Gentile, et al [7]. The seismic fragility curve can be seen in Fig. 1 below.
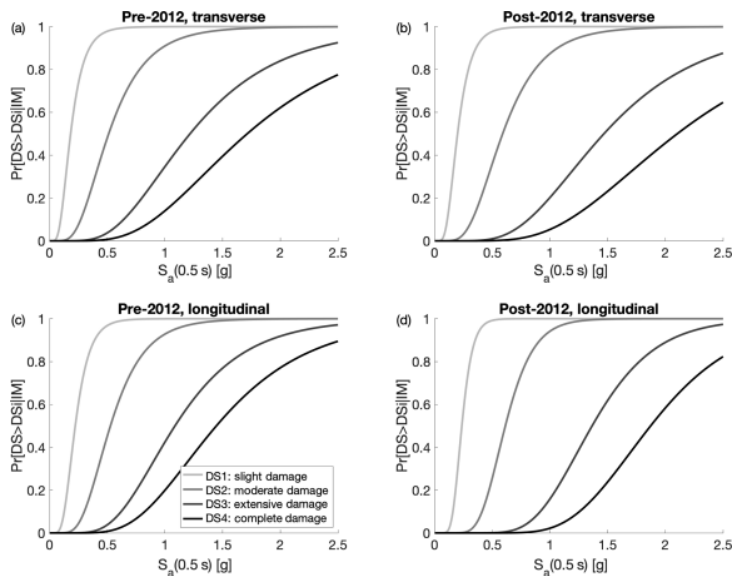

Fig. 1. Typical seismic fragility curve of school buildings. Gentile [7]

The limits of structural damage according to Hazus can be seen in Table 2 . 
Table 2. Description of damage states based on Hazus.

\begin{tabular}{|c|c|}
\hline Damage states & Description of the damage \\
\hline $\begin{array}{c}\text { Slight/Minor } \\
\text { Damage }\end{array}$ & $\begin{array}{l}\text { Small plaster cracks at corners of door } \\
\text { and window openings and wall-ceiling } \\
\text { intersections; small cracks in masonry } \\
\text { chimneys and masonry veneers. Small } \\
\text { cracks are assumed to be visible with a } \\
\text { maximum width of less than } 1 / 8 \text { inch } \\
\text { (cracks wider than } 1 / 8 \text { inch are referred } \\
\text { to "large" cracks) }\end{array}$ \\
\hline $\begin{array}{c}\text { Moderate } \\
\text { Damage }\end{array}$ & $\begin{array}{l}\text { Large plaster or gypsum-board cracks at } \\
\text { corners of door and window openings; } \\
\text { small diagonal cracks across shear wall } \\
\text { panels exhibited by small cracks in } \\
\text { stucco and gypsum wall panels; large } \\
\text { cracks in brick chimneys; toppling of tall } \\
\text { masonry chimneys. }\end{array}$ \\
\hline $\begin{array}{c}\text { Extensive } \\
\text { Damage }\end{array}$ & $\begin{array}{l}\text { Large diagonal cracks across shear wall } \\
\text { panels or large cracks at plywood joints; } \\
\text { permanent lateral movement of floors } \\
\text { and roof; toppling of most brick } \\
\text { chimneys; cracks in foundations; } \\
\text { splitting of wood sill plates and/or } \\
\text { slippage of structure over foundations. }\end{array}$ \\
\hline $\begin{array}{c}\text { Complete } \\
\text { Damage }\end{array}$ & $\begin{array}{l}\text { Structure may have large permanent } \\
\text { lateral displacement or be in imminent } \\
\text { danger of collapse due to cripple wall } \\
\text { failure or failure of the lateral load } \\
\text { resisting system; some structures may } \\
\text { slip and fall off the foundation; large } \\
\text { foundation cracks. Three percent of the } \\
\text { total area of buildings with Complete } \\
\text { damage is expected to be collapsed, on } \\
\text { average. }\end{array}$ \\
\hline
\end{tabular}

Source: Hazus [2]

According to Koshimura, et al [8], the tsunami fragility curve is a way to estimate structural damage due to the tsunami hazard, by integrating field surveys and analyzing data from geographic information systems. The tsunami fragility curve represents the probability of structural damage related to the inundation depth as shown in Fig. 2. Tsunami fragility curve based on Syamsidik, et al [9].

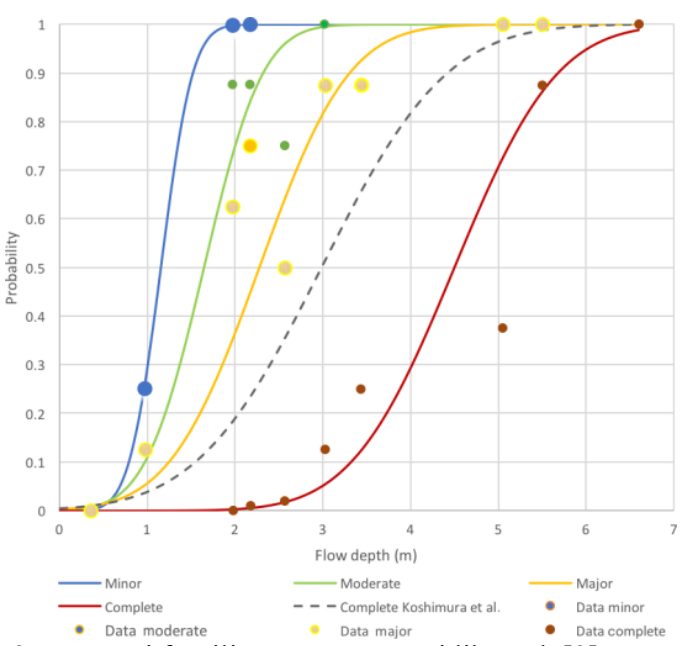

Fig. 2. Tsunami fragility curve, Syamsidik et al. [9]

Table 3. Damage states to building due to tsunami, based Syamsidik et al. [9]

\begin{tabular}{ccl}
\hline Classification & $\begin{array}{c}\text { Damage } \\
\text { Condition }\end{array}$ & \multicolumn{1}{c}{ Description } \\
\hline DCO & $\begin{array}{c}\text { No } \\
\text { damages }\end{array}$ & $\begin{array}{l}\text { Flooded but no damages } \\
\text { found. }\end{array}$ \\
\hline DC1 & Minor & $\begin{array}{l}\text { Damages found windows } \\
\text { and doors, no damage on } \\
\text { wall and on structural } \\
\text { component }\end{array}$ \\
\hline DC2 & Moderate & $\begin{array}{l}\text { One side wall damages, no } \\
\text { damage on column and } \\
\text { beam. }\end{array}$ \\
\hline DC3 & Major & $\begin{array}{l}\text { All walls were damaged or } \\
\text { roofs felt down, structural } \\
\text { components bent/deflected } \\
\text { or broken. }\end{array}$ \\
DC4 & $\begin{array}{c}\text { Complatel } \\
\text { Washed } \\
\text { away }\end{array}$ & Only floor left. \\
\hline
\end{tabular}

Source: Syamsidik et al. [9]

\section{Research methods}

\subsection{Data collection techniques}

Research data collection was done by field survey. Field surveys are used to collect data on building structures and building vulnerability factors by looking directly at the condition of the building. The survey was conducted on 100 school buildings in Banda Aceh City using a rapid visual survey so that the distribution of buildings was achieved for each sub-district location in Banda Aceh City.

\subsubsection{Building structure data}

The data of the structure building in this study uses and the data based on direct observation of the buildings as shown in Table 4 and typical details of building structures based on the research of Gentile [7], which are typical details of building structures for various forms of buildings in Banda Aceh as shown in Table 5.

Table 4. The data based on direct observation of the buildings

\begin{tabular}{lcccc}
\hline School & $\begin{array}{c}\text { Height } \\
(\mathbf{m})\end{array}$ & $\begin{array}{c}\text { Columns } \\
(\mathbf{m})\end{array}$ & $\begin{array}{c}\text { Beams } \\
(\mathbf{m})\end{array}$ & Material \\
\hline SDN 48 & 3.5 & $0.3 \times 0.3$ & $0.3 \times 0.4$ & $\mathrm{RC}$ \\
\hline SDN 08 & 3.5 & $0.3 \times 0.3$ & $0.3 \times 0.4$ & $\mathrm{RC}$
\end{tabular}


Table 5. Typical quality of concrete and steel reinforcement for school buildings in Banda Aceh City.

\begin{tabular}{|c|c|c|c|c|}
\hline & Material & $\begin{array}{l}\text { Typical } \\
\text { Beam }\end{array}$ & $\begin{array}{l}\text { Typical } \\
\text { Column }\end{array}$ & $\begin{array}{c}\text { Typical } \\
\text { Joint }\end{array}$ \\
\hline \multirow{3}{*}{ Pre-2012 } & $\begin{array}{l}\text { Concrete } \\
\mathrm{f}_{\mathrm{c}}=21,5 \\
\mathrm{MPa}\end{array}$ & $\begin{array}{l}3 \Phi 16 \\
\text { top }\end{array}$ & $\begin{array}{l}3 \Phi 16 \\
\text { top }\end{array}$ & $\begin{array}{c}\text { No } \\
\text { stirrups }\end{array}$ \\
\hline & $\begin{array}{l}\text { Long. } \\
\text { Steel } \mathrm{f}_{\mathrm{y}}= \\
400 \mathrm{MPa}\end{array}$ & $\begin{array}{l}3 \Phi 16 \\
\text { bottom }\end{array}$ & $\begin{array}{l}3 \Phi 16 \\
\text { bottom }\end{array}$ & \\
\hline & $\begin{array}{l}\text { Tran. } \\
\text { Steel } \mathrm{f}_{\mathrm{y}}= \\
240 \mathrm{MPa}\end{array}$ & $\begin{array}{l}\Phi 10 @ 1 \\
50 \mathrm{~mm} \\
\text { stirrups }\end{array}$ & $\begin{array}{l}\Phi 10 @ 2 \\
00 \mathrm{~mm} \\
\text { stirrups }\end{array}$ & \\
\hline \multirow{3}{*}{ Post-2012 } & $\begin{array}{l}\text { Concrete } \mathrm{f}_{\mathrm{c}} \\
=24 \mathrm{MPa}\end{array}$ & $3 \Phi 16$ top & $\begin{array}{l}3 \Phi 16 \\
\text { top }\end{array}$ & $\begin{array}{c}\text { No } \\
\text { stirrups }\end{array}$ \\
\hline & $\begin{array}{l}\text { Long. } \\
\text { Steel } \mathrm{f}_{\mathrm{y}}= \\
400 \mathrm{MPa}\end{array}$ & $\begin{array}{l}3 \Phi 16 \\
\text { bottom }\end{array}$ & $\begin{array}{l}3 \Phi 16 \\
\text { bottom }\end{array}$ & \\
\hline & $\begin{array}{l}\text { Tran. Steel } \\
\mathrm{f}_{\mathrm{y}}=240 \\
\mathrm{MPa}\end{array}$ & $\begin{array}{l}\text { Ф10@150 } \\
\text { mm } \\
\text { stirrups }\end{array}$ & $\begin{array}{l}\text { Ф10@1 } \\
00 \text { mm } \\
\text { stirrups }\end{array}$ & \\
\hline
\end{tabular}

Source: Gentile [7]

\subsubsection{Earthquake data}

Earthquake data used is the Sumatra - Andaman earthquake on December 26, 2004 obtained from the United States Geological Survey (USGS) and earthquake forecast data from the 2017 Indonesia seismic hazard map obtained from PUSKIM were in the form of a response spectrum.

\subsubsection{Tsunami data}

The data needed to calculate the tsunami load is the depth of the 2004 tsunami flow and the difference between the subgrade of the building and the water level. The estimated height of the tsunami inundation in Banda Aceh City was obtained from the research of Iemura, et al [10].

\subsection{Structure modeling}

The structural system that will be modeled by using SAP2000 is space frame structure. the data needed for the structural model is building data which is the dimensions of the building, concrete materials used and also peak ground acceleration data. Structural modeling was carried out for two typical buildings.

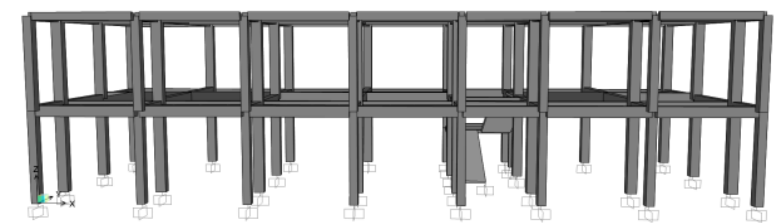

Fig. 3. School building structure model in 3D

\subsection{Structure loads}

The loads that are input into the SAP2000 program are loads that are reviewed in the structural design which is dead loads, live loads, earthquake loads, tsunami loads and load combination.

1. Earthquake combination loads

$$
\begin{aligned}
& \mathrm{U} 1=1,4 \mathrm{D} \\
& \mathrm{U} 2=1,2 \mathrm{D}+1,6 \mathrm{~L} \\
& \mathrm{U} 3=1,38 \mathrm{D}+1 \mathrm{~L}+0,39 \mathrm{QEx}+1,3 \mathrm{QEy} \\
& \mathrm{U} 4=1,38 \mathrm{D}+1 \mathrm{~L}+0,39 \mathrm{QEx}-1,3 \mathrm{QEy} \\
& \mathrm{U} 5=1,38 \mathrm{D}+1 \mathrm{~L}-0,39 \mathrm{QEx}-1,3 \mathrm{QEy} \\
& \mathrm{U} 6=1,38 \mathrm{D}+1 \mathrm{~L}-0,39 \mathrm{QEx}+1,3 \mathrm{QEy} \\
& \mathrm{U} 7=1,38 \mathrm{D}+1 \mathrm{~L}+1,3 \mathrm{QEx}+0,39 \mathrm{QEy} \\
& \mathrm{U} 8=1,38 \mathrm{D}+1 \mathrm{~L}+1,3 \mathrm{QEx}-0,39 \mathrm{QEy} \\
& \mathrm{U} 9=1,38 \mathrm{D}+1 \mathrm{~L}-1,3 \mathrm{QEx}-0,39 \mathrm{QEy} \\
& \mathrm{U} 10=1,38 \mathrm{D}+1 \mathrm{~L}-1,3 \mathrm{QEx}+0,39 \mathrm{QEy} \\
& \mathrm{U} 11=1,08 \mathrm{D}+0,39 \mathrm{QEx}+1,3 \mathrm{QEy} \\
& \mathrm{U} 12=1,08 \mathrm{D}+0,39 \mathrm{QEx}-1,3 \mathrm{QEy} \\
& \mathrm{U} 13=1,08 \mathrm{D}-0,39 \mathrm{QEx}-1,3 \mathrm{QEy} \\
& \mathrm{U} 14=1,08 \mathrm{D}-0,39 \mathrm{QEx}+1,3 \mathrm{QEy} \\
& \mathrm{U} 15=1,08 \mathrm{D}+1,3 \mathrm{QEx}-0,39 \mathrm{QEy} \\
& \mathrm{U} 16=1,08 \mathrm{D}+1,3 \mathrm{QEx}+0,39 \mathrm{QEy} \\
& \mathrm{U} 17=1,08 \mathrm{D}-1,3 \mathrm{QEx}-0,39 \mathrm{QEy} \\
& \mathrm{U} 18=1,08 \mathrm{D}-1,3 \mathrm{QEx}+0,39 \mathrm{QEy}
\end{aligned}
$$

2. Tsunami combination loads

$$
\begin{aligned}
& \mathrm{U} 19=1,2 \mathrm{D}+1,0 \mathrm{TS}+1,0 \mathrm{LREF}+0,25 \mathrm{~L} \\
& \mathrm{U} 20=0,9 \mathrm{D}+1,0 \mathrm{TS}
\end{aligned}
$$

\subsection{Pushover analysis}

pushover analysis was carried out by gradual increased load, lateral load was carried out representing the earthquake force on each floor. The direction of lateral loading is carried out in the direction of the main axis of the building. Lateral loading uses the displacementcontrolled concept, namely the loading process is gradually increased until the displacement target is achieved.

\subsection{Tsunami analysis}

In analyzing the tsunami load, the used loads are hydrostatic load, hydrodynamic load and debris impact load. Hydrostatic load occurs when water moves closer to structure as a distributed load, pyramid-shaped along the flooded column. Hydrodynamic load as a distributed load along a flooded column. debris impact load is entered as point load. These loads are entered in the $y$ direction. Next, an analysis is carried out on the SAP2000 program using tsunami combination load.

\subsection{Data analysis}

\subsubsection{Capacity curve analysis and spectrum capacity curve analysis}

In the SAP2000 program, the results of the pushover analysis obtained a capacity curve that shows the behavior of the structure when the shearing force is applied at a certain level, response spectrum curves that suitable for the existing earthquake region, yield 
diagrams of plastic hinges in beams and columns. An analysis of the spectrum capacity curve obtained from the pushover analysis was carried out to obtain the median spectral displacement value for each damage condition. The median spectral displacement value for each damage condition will be described in a log scale on the seismic fragility curve with a probability value of $50 \%$ and is used to determine limit state for each damage [11].

\subsubsection{Seismic fragility curve analysis and tsunami fragility curve analysis}

Seismic fragility curve was used to see the probability of structural failure when receiving earthquake loads with a certain intensity based on the fragility curve that has been developed. A probability value was obtained by looking at the coordinates of the fragility curve axis (y) with a value of Sa. In using the graphreader application, take one of the fragility curve was taken from previous studies. The step in reading curve values was to select a png, jpg or gif image and push 'Go', resize the blue rectangle to set the ruler for axis scaling as in Fig.4. Set values for the appropriate $\mathrm{x}$ and $\mathrm{y}$-axis scaling. Then double click to enter a curve fix point. Click 'Generate curve' to see the output data as shown in Fig.5.

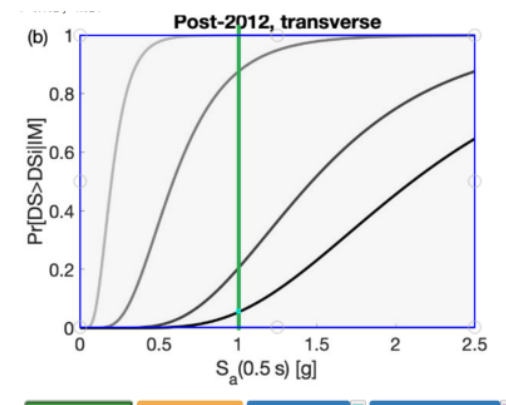

Fig. 4. Imputting Images and Dots on Graphics

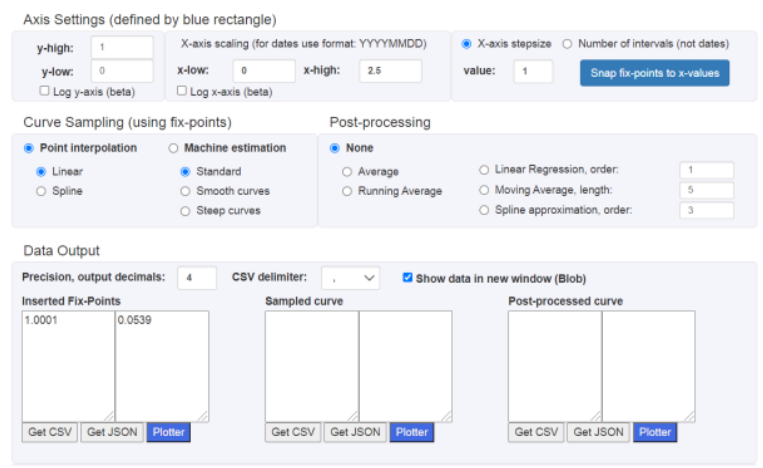

Fig. 5. Graphics output data results

From the results of this analysis, it is found that the structural performance limits indicate the probability of damage to the building structure for various damage conditions, namely slight damage, moderate damage, extensive damage, and complete damage.

\section{Results and discussion}

\subsection{Results of school building recapitulation}

Based on the results of the rapid visual survey, the criteria for school buildings in Banda Aceh are as follows.
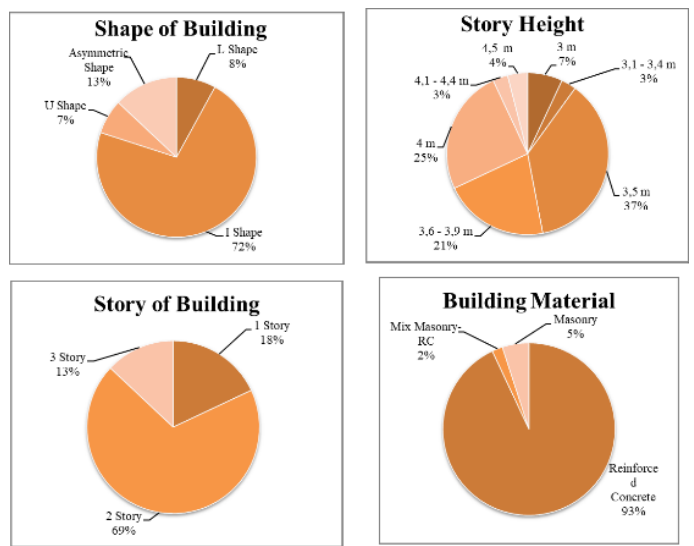

Fig. 6. Percentage graph of data survey results of 100 school buildings

It can be concluded that the typical dominant schools in Banda Aceh City are as follows:

- Building form : Tipe I (Top view)

- Number of floor : 2

- Height each floor : $3,5 \mathrm{~m}$

- Constituent material : Reinforce concrete

From the survey results, the two buildings selected were SDN 48 and SDN 8. Another reason for choosing this school building is because it is relatively close to the beach and the 2004 tsunami inundation height was recorded at that location.

\subsection{Fundamental period structure}

From the results of SAP2000, the natural fundamental period time $\mathrm{T}=0.2274$ for SDN 48 and $\mathrm{T}=0.2209$ for SDN 8 with Ta max obtained from the calculation of SNI 1726-2019 of 0.3759. So, T analysis $<$ Ta max, then the structure is declared to have met the conditions for the permit fundamental period obtained from the calculation of SNI 1726-2019.

\subsection{The results of inter story drift analysis earthquake load}

The results of the calculation of the inter-story drift for school buildings in the $\mathrm{x}$-direction and $\mathrm{y}$-direction can be seen in Fig. 7 and Fig.8.

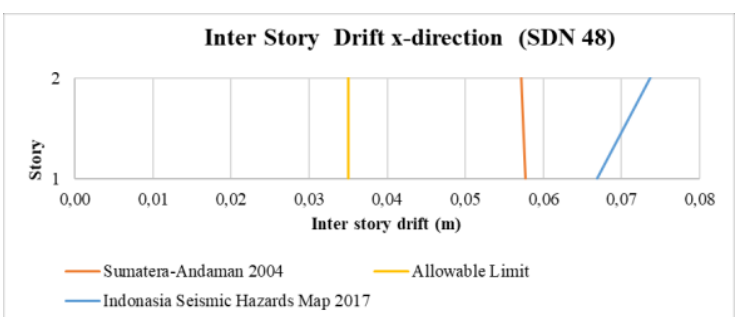

Fig. 7. The inter story drift due to earthquake load $\mathrm{x}$-direction (continued) 


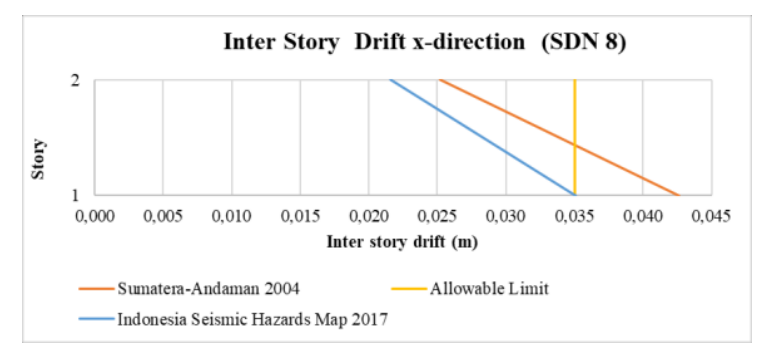

Fig. 7. The inter story drift due to earthquake load $\mathrm{x}$-direction

Based on Fig.7 the results of inter story drift in the $\mathrm{x}$ direction at SDN 48 and SDN 8 with the Sumatera Andaman 2004 earthquake load and from the 2017 Indonesia seismic hazard map, it can be seen that these results do not meet the inter story drift permit levels from the provisions of SNI 1726-2019.

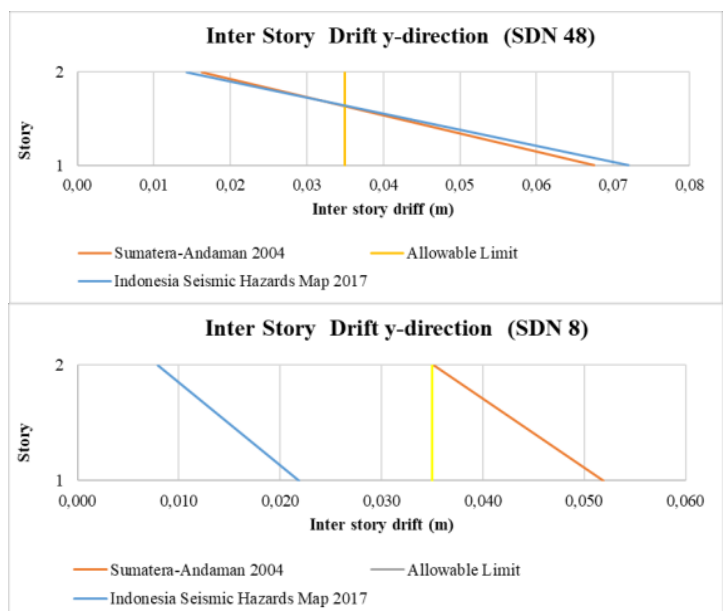

Fig. 8. The inter story drift due to earthquake load y-direction

Based on Fig. 8 the results of the calculation of inter story drift in the y direction in the SDN 48 and SDN 8 buildings with the 2004 Sumatra - Andaman earthquake load and the 2017 Indonesia seismic hazard map can be seen that these results also do not meet the inter story drift permit's levels from the provisions of SNI 17262019.

\subsection{Capacity curve}

The capacity curve is nonlinear due to an increase in load that makes the structural elements of the building change from an elastic condition to a plastic condition, to make the capacity curve clearer for the Sumatera Andaman earthquake 2004 and earthquake load from the Indonesian seismic hazard map in the $\mathrm{x}$ and $\mathrm{y}$ directions

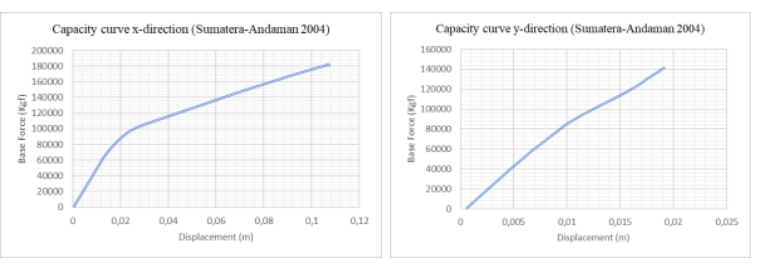

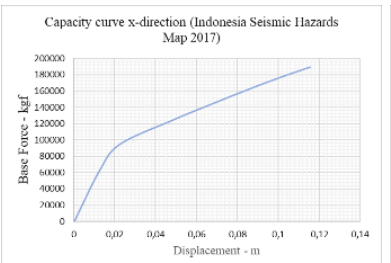

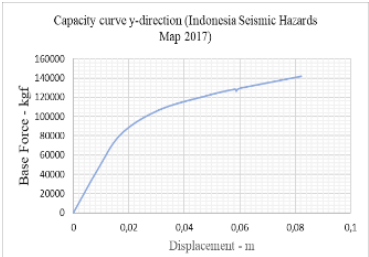

Fig. 9. The capacity curve of SDN 48 building
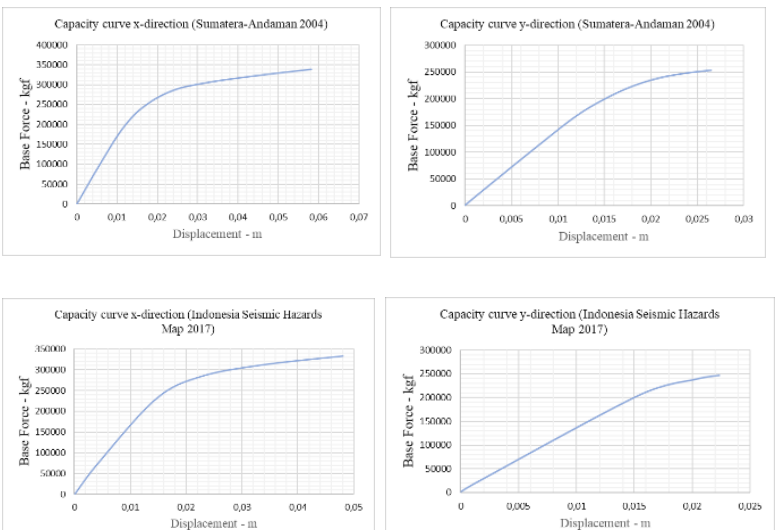

Fig. 10. The capacity curve of SDN 08 building

\subsection{Spectrum capacity curve}

The capacity spectrum curve is used to obtain the median spectral displacement value. The conversion of the capacity spectrum curve is carried out with the SAP2000 program from the results of the capacity curve. To determine the damage states from the capacity spectrum curve, it was carried out based on research Duan and Papin [11]. The position of each damage state on the capacity spectrum curve for SDN 48 and SDN 08 with the 2004 Andaman earthquake.

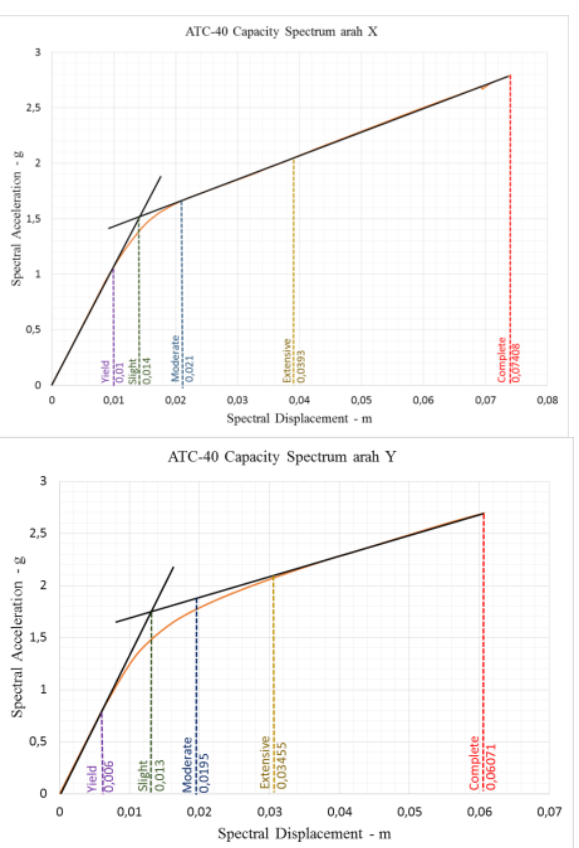

Fig. 11. Damage states determine SDN 48 (SumateraAndaman earthquake 2004) 


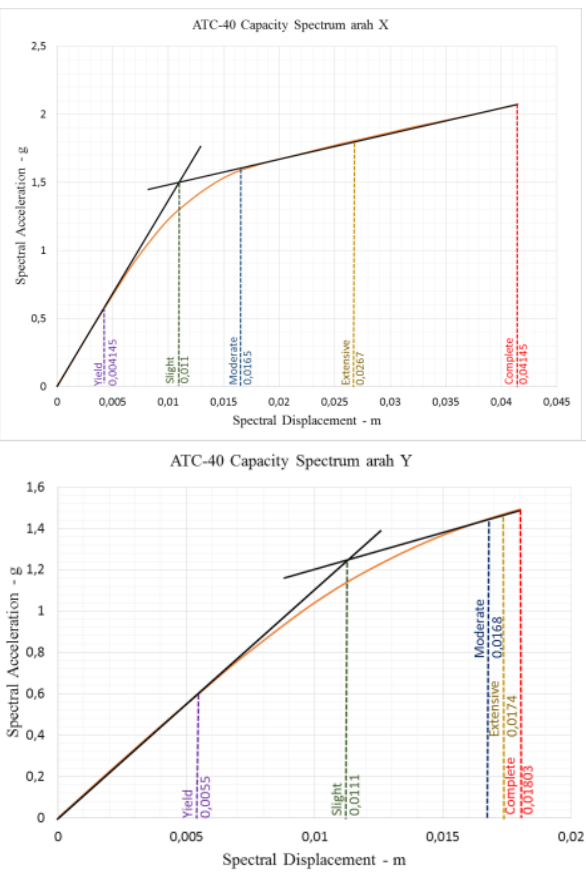

Fig. 12. Damage states determine SDN 08 (SumateraAndaman earthquake 2004)

Meanwhile, with the indonesia sesmic hazards map 2017, the damage states on the capacity spectrum curve for SDN 48 and SDN 8 are as follows.

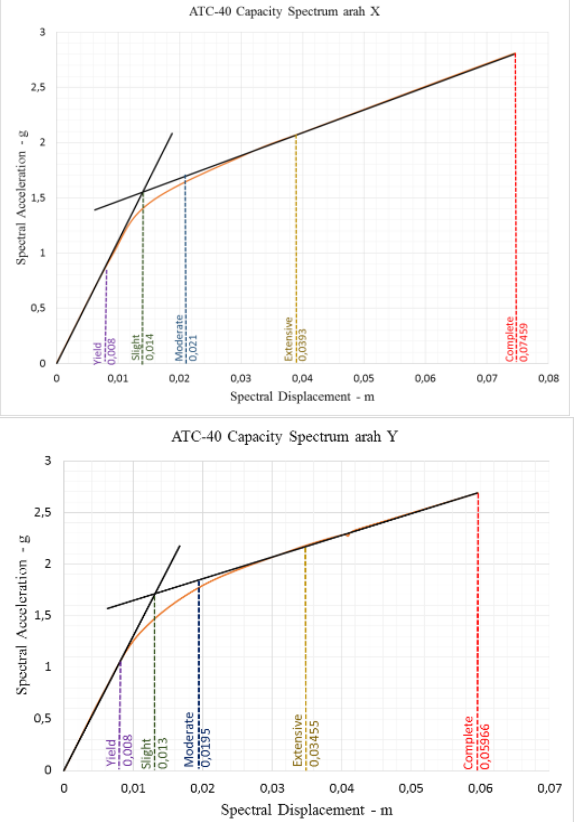

Fig. 13. Damage states determine SDN 48 (Indonesia seismic hazards map 2017)

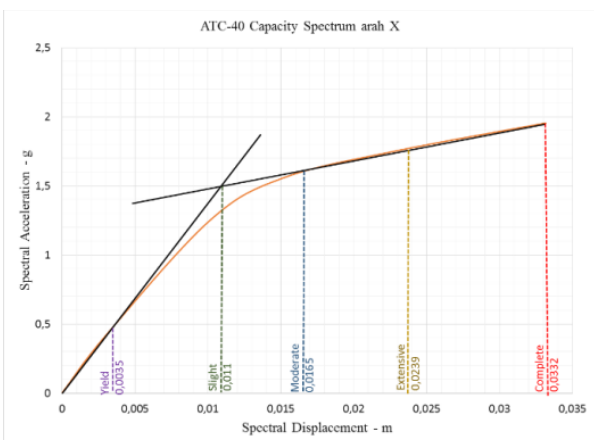

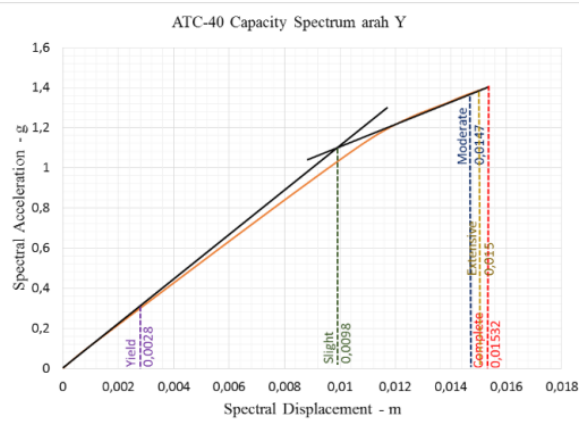

Fig. 14. Damage states determine SDN 08 (Indonesia seismic hazards map 2017)

Based on the identification of the capacity spectrum curve, the spectral displacement and spectral acceleration points for each structural failure condition are generated as shown in the following table:

Tabel 6. Sd and Sa values for various conditions of damage to SDN 48

\begin{tabular}{|c|c|c|c|c|c|}
\hline \multirow{2}{*}{$\begin{array}{c}\text { Seismic } \\
\text { Type }\end{array}$} & \multirow{2}{*}{$\begin{array}{c}\text { Demage } \\
\text { state }\end{array}$} & \multicolumn{2}{|c|}{$S_{d}, d s(m)$} & \multicolumn{2}{|c|}{ Sa,ds (g) } \\
\hline & & $\mathbf{x}$ & $\mathbf{y}$ & $\mathbf{x}$ & $\mathbf{y}$ \\
\hline \multirow{4}{*}{$\begin{array}{l}\text { Sumatera- } \\
\text { Andaman } \\
2004\end{array}$} & Slight & 0,0140 & 0,0130 & 1,3808 & 1,4681 \\
\hline & Moderate & 0,0210 & 0,0195 & 1,6613 & 1,7666 \\
\hline & Extensive & 0,0393 & 0,0346 & 2,0545 & 2,1640 \\
\hline & Complete & 0,0741 & 0,0607 & 2,7928 & 2,6956 \\
\hline \multirow{4}{*}{$\begin{array}{l}\text { Indonesia } \\
\text { Seismic } \\
\text { Hazards } \\
\text { Map } 2017\end{array}$} & Slight & 0,0140 & 0,0130 & 1,3638 & 1,4387 \\
\hline & Moderate & 0,02100 & 0,0195 & 1,6178 & 1,7674 \\
\hline & Extensive & 0,0393 & 0,0346 & 2,0746 & 2,1683 \\
\hline & Complete & 0,0741 & 0,0597 & 2,8099 & 2,6899 \\
\hline
\end{tabular}

Tabel 7. Sd and Sa values for various conditions of damage to SDN 08

\begin{tabular}{llcccc}
\hline \multicolumn{1}{c}{$\begin{array}{c}\text { Seismic } \\
\text { Type }\end{array}$} & \multirow{2}{*}{$\begin{array}{c}\text { Demage } \\
\text { state }\end{array}$} & \multicolumn{2}{c}{$\mathbf{S}_{\mathbf{d}}, \mathbf{d s}(\mathbf{m})$} & \multicolumn{2}{c}{ Sa,ds $(\mathbf{g})$} \\
\cline { 3 - 6 } & & $\mathbf{x}$ & $\mathbf{y}$ & $\mathbf{x}$ & $\mathbf{y}$ \\
\hline Sumatera- & Slight & 0,0110 & 0,0111 & 1,3015 & 1,1303 \\
\cline { 2 - 6 } Andaman & Moderate & 0,01650 & 0,0168 & 1,5869 & 1,4464 \\
\cline { 2 - 6 } $\mathbf{2 0 0 4}$ & Extensive & 0,0267 & 0,0174 & 1,8040 & 1,4694 \\
\cline { 2 - 6 } & Complete & 0,0414 & 0,0180 & 2,0706 & 1,4914 \\
\hline Indonesia & Slight & 0,0110 & 0,0098 & 1,3016 & 1,0153 \\
Seismic & Moderate & 0,01650 & 0,0147 & 1,5914 & 1,3684 \\
Hazards & Extensive & 0,0239 & 0,0150 & 1,7715 & 1,3841 \\
Map 2017 & Complete & 0,0332 & 0,0153 & 1,9549 & 1,4006
\end{tabular}

\subsection{Results of tsunami load analysis}

The results of the tsunami load analysis obtained the inter-level deviation where the control for the deviation between the permit levels was used SNI 1726-2019. 
Table 8. Inter story drift in x direction of SDN 48.

\begin{tabular}{ccccc}
\hline Floor & Height & $\begin{array}{c}\text { Displacem } \\
\text { ent } y\end{array}$ & $\begin{array}{c}\text { Inter-floor } \\
\text { drift }\end{array}$ & $\begin{array}{c}\text { Inter-floor } \\
\text { drift } \\
\text { permit } \\
\left(0,010 \mathrm{~h}_{\mathrm{sx}}\right)\end{array}$ \\
\hline & $(\mathrm{m})$ & $(\mathrm{m})$ & $(\mathrm{m})$ & $(\mathrm{m})$ \\
\hline 2 & 3.5 & 0.014475 & 0.001299 & 0.035 \\
\hline 1 & 3.5 & 0.013176 & 0.013176 & 0.035
\end{tabular}

Table 9. Inter story drift in y direction of SDN 48.

\begin{tabular}{ccccc}
\hline Floor & Height & $\begin{array}{c}\text { Displacem } \\
\text { ent } y\end{array}$ & $\begin{array}{c}\text { Inter-floor } \\
\text { drift }\end{array}$ & $\begin{array}{c}\text { Inter-floor } \\
\text { drift } \\
\text { permit } \\
\left(0,010 \mathrm{~h}_{\mathrm{sx}}\right)\end{array}$ \\
\hline & $(\mathrm{m})$ & $(\mathrm{m})$ & $(\mathrm{m})$ & $(\mathrm{m})$ \\
\hline 2 & 3.5 & 0.067058 & 0.017171 & 0.035 \\
\hline 1 & 3.5 & 0.049887 & 0.049887 & 0.035
\end{tabular}
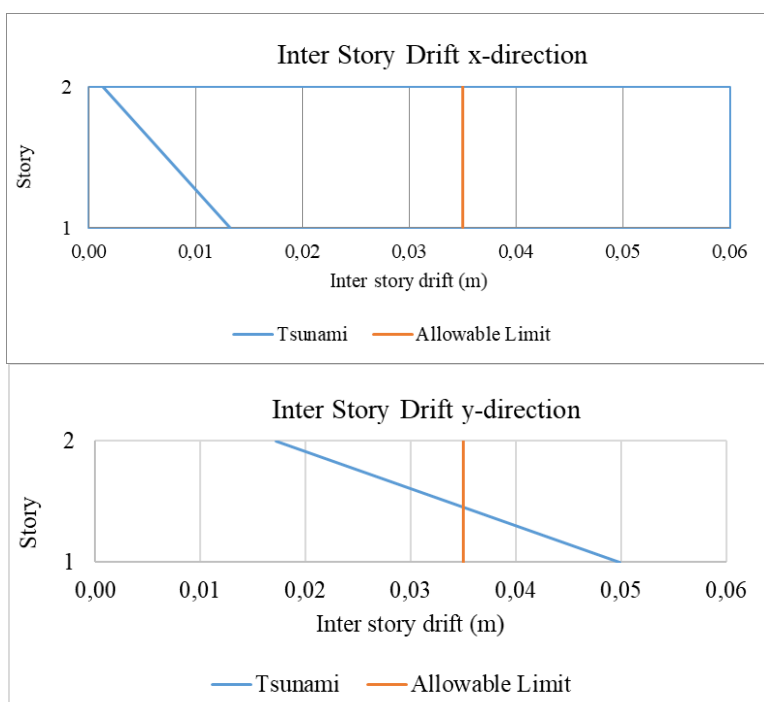

Fig.15. Inter story drift due to tsunami load at SDN 48

As for the deviation between floors for SDN 8 buildings in the $\mathrm{x}$-direction and the $\mathrm{y}$-direction

Table 10. Inter story drift in y direction of SDN 08.

\begin{tabular}{ccccc}
\hline Floor & Height & $\begin{array}{c}\text { Displacem } \\
\text { ent y }\end{array}$ & $\begin{array}{c}\text { Inter-floor } \\
\text { drift }\end{array}$ & $\begin{array}{c}\text { Inter-floor } \\
\text { drift } \\
\text { permit } \\
\left(0,010 \mathrm{~h}_{\mathrm{sx}}\right)\end{array}$ \\
\hline & $(\mathrm{m})$ & $(\mathrm{m})$ & $(\mathrm{m})$ & $(\mathrm{m})$ \\
\hline 2 & 3.5 & 0.001959 & 0.000366 & 0.035 \\
\hline 1 & 3.5 & 0.001593 & 0.001593 & 0.035
\end{tabular}

Table 11. Inter story drift in y direction of SDN 08.

\begin{tabular}{ccccc}
\hline Floor & Height & $\begin{array}{c}\text { Displacem } \\
\text { ent y }\end{array}$ & $\begin{array}{c}\text { Inter-floor } \\
\text { drift }\end{array}$ & $\begin{array}{c}\text { Inter-floor } \\
\text { drift } \\
\text { permit } \\
\left(0,010 \mathrm{~h}_{\mathrm{sx}}\right)\end{array}$ \\
\hline & $(\mathrm{m})$ & $(\mathrm{m})$ & $(\mathrm{m})$ & $(\mathrm{m})$ \\
\hline 2 & 3.5 & 0.054206 & 0.014351 & 0.035 \\
\hline 1 & 3.5 & 0.039855 & 0.039855 & 0.035
\end{tabular}

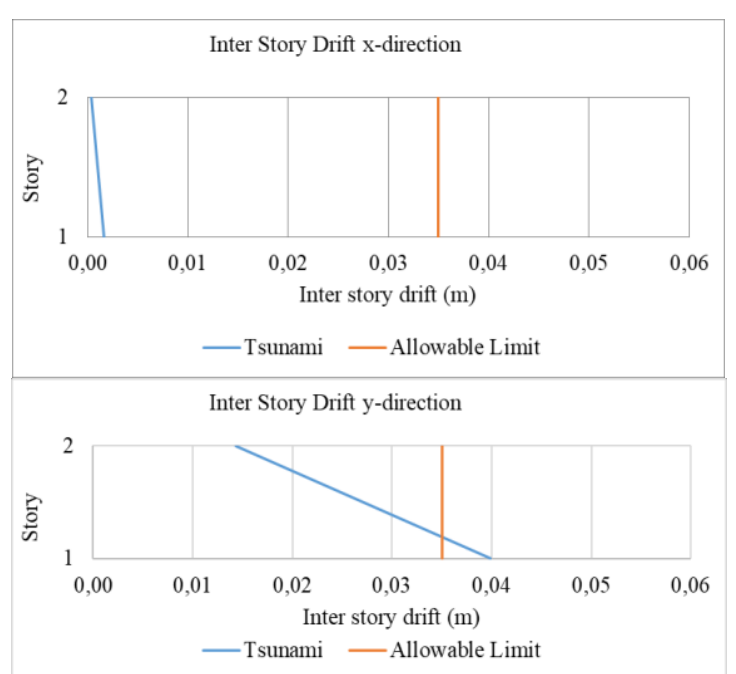

Fig. 16. Inter-Story drift due to tsunami load at SDN 08

Based on the results of the deviation between floors due to the tsunami load at SDN 48 and SDN 8, the deviation between floors in the $\mathrm{y}$ direction has an inter-floor deviation value that exceeds the allowable inter-floor deviation based on SNI 1726-2019. Due to the depth of the tsunami inundation at that location has reached the second floor.

\subsection{Determination of damage states}

The data needed is obtained from the results of the Puskim Spectra response program. In Puskim earthquake modeling, the results of the Spectra program for SDN 48 are as follows:

$\mathrm{T}=0,3759 \mathrm{~s}$
$\mathrm{~T}_{0}=0,135983 \mathrm{~s}$
$\mathrm{Ts}=0,679916 \mathrm{~s}$
$\mathrm{TL}=14,00000 \mathrm{~s}$
$\mathrm{Sds}=1,000124 \mathrm{~g}$

For SDN 48 buildings, the fundamental period of the building $(\mathrm{T})$ is greater than or equal to $\mathrm{T} 0$ and less than or equal to $\mathrm{Ts}$, the design acceleration response spectrum $(\mathrm{Sa})$ is the same as SDS. Then the value of the acceleration spectrum $(\mathrm{Sa})=1.000124 \mathrm{~g}$. Meanwhile, the results of the Spectra program for SDN 8 are as follows:

$\mathrm{T}=0,3759 \mathrm{~s}$
$\mathrm{~T} 0=0,135831 \mathrm{~s}$
$\mathrm{Ts}=0,679154 \mathrm{~s}$
$\mathrm{TL}=15,00000 \mathrm{~s}$
$\mathrm{Sds}=1,001245 \mathrm{~g}$

For an SDN 8 building, the fundamental period of the building $(\mathrm{T})$ is greater than or equal to $\mathrm{T} 0$ and less than or equal to $\mathrm{Ts}$, the design acceleration response spectrum ( $\mathrm{Sa})$ is the same as $\mathrm{SDS}$, so the acceleration spectrum $(\mathrm{Sa})=1.001245 \mathrm{~g}$. Then the position of the damage state for the value of $\mathrm{Sa}$ is as follows: 


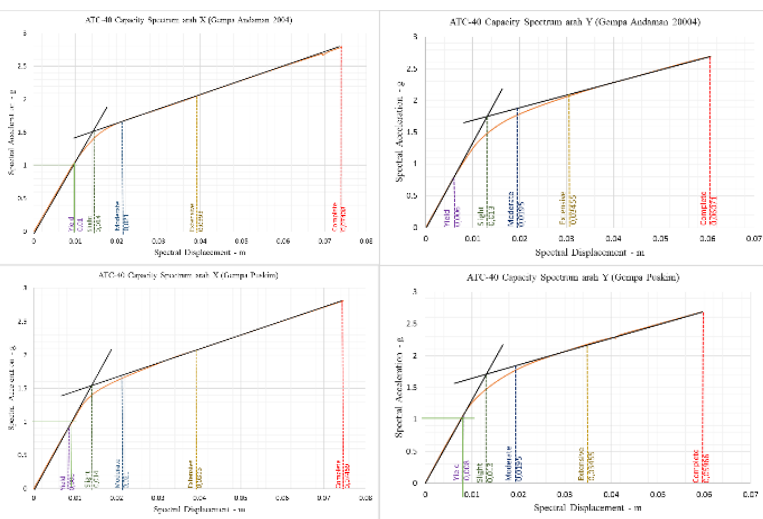

Fig. 17. Determination of the position of the damage state based on the value of Sa on the SDN 48

Based on Fig. 17 it can be seen that SDN 48 with a load of the 2004 Andaman earthquake and the Puskim earthquake at a Sa value of 1,000124 is in the $\mathrm{x}$ direction and the $y$ direction is between yield and slight conditions.

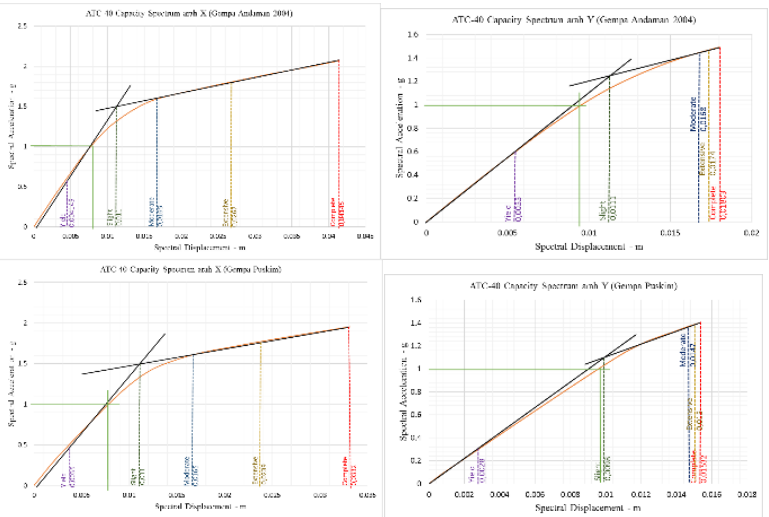

Fig. 18. Determination of the position of the damage state based on the value of Sa on the SDN 08

Based on Fig. 18 it can be seen that SDN 08 with the load of the 2004 Andaman earthquake and the Puskim earthquake at a Sa value of 1.001245 is in the $\mathrm{x}$ direction and the y direction is between yield conditions and close to slight damage.

\subsection{Probability value based on the developed fragility curve}

Based on research by Gentile [7], the probability value of building failure for each damage condition can be known by looking at the previous curve based on the obtained Sa value. Where the data Sa for SDN 48 $1.000124 \mathrm{~g}$ is inputted in the graphreader application so that the probability value of the output data results is a curve for SDN 48 as follows:
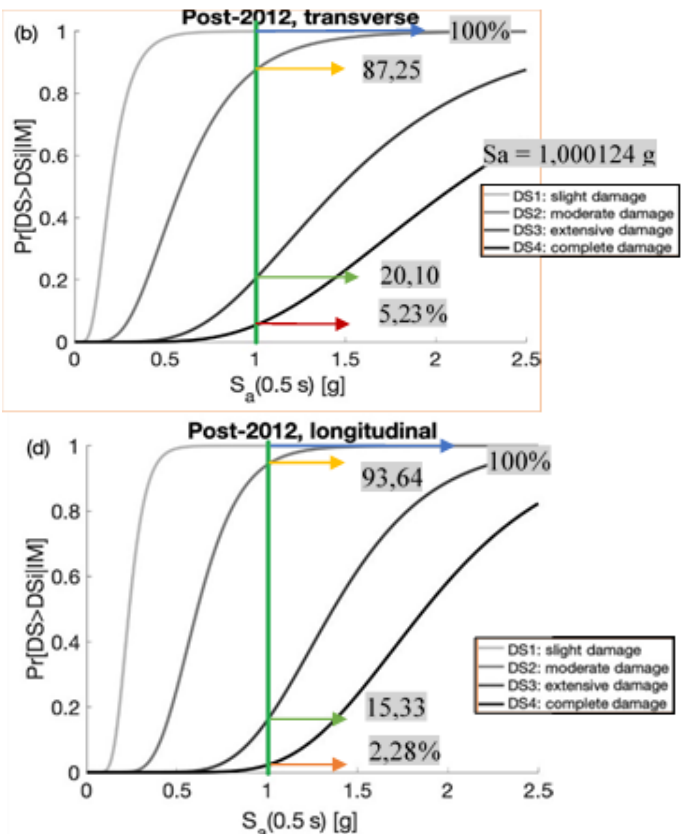

Fig. 19. Identification of the seismic fragility curve of the SDN 48 building in the $\mathrm{x}$ and $\mathrm{y}$ directions

As for the SDN 8 Sa data obtained is $1.001245 \mathrm{~g}$ so that the probability value obtained from the results of the curve output data for SDN 8 is as follows:
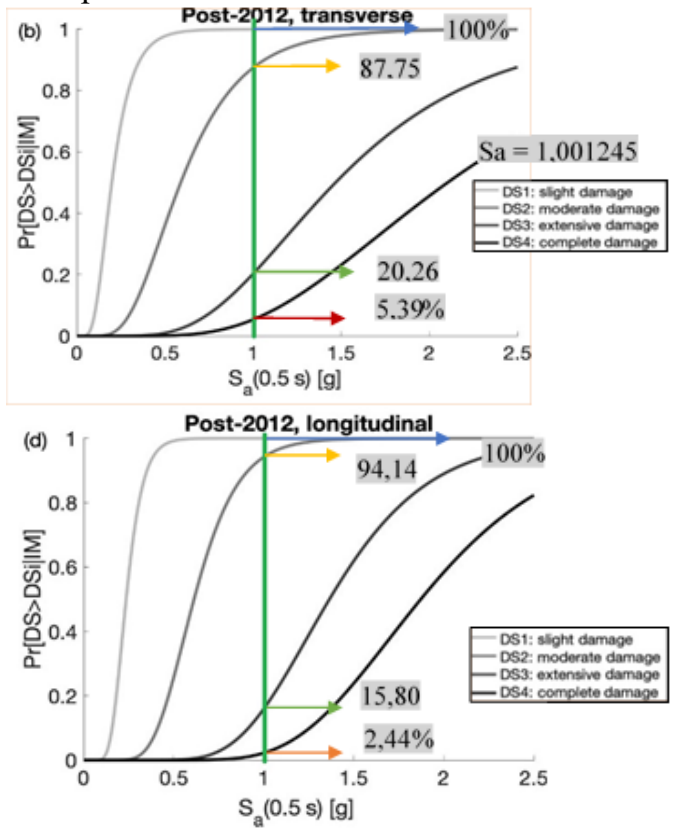

Fig. 20. Identification of the seismic fragility curve of the SDN 08 building in the $\mathrm{x}$ and $\mathrm{y}$ directions

From the results of the evaluation of the comparison of damage limits based on the spectrum capacity curve to the Sa values of 1,000124 and 1.001245 for the SDN 48 and SDN 8 buildings, it was found that the damage conditions were in the boundary between yield and slight damage, while the evaluation was carried out on the fragility curve that had been developed. against the Sa value of 1.000124 and 1.00124 for the school, it was found that large damage occurred in conditions of slight damage and moderate damage. 
Evaluation of the probability of damage due to tsunami loads is carried out based on the tsunami fragility curve that has been developed by Syamsidik, et al [9].

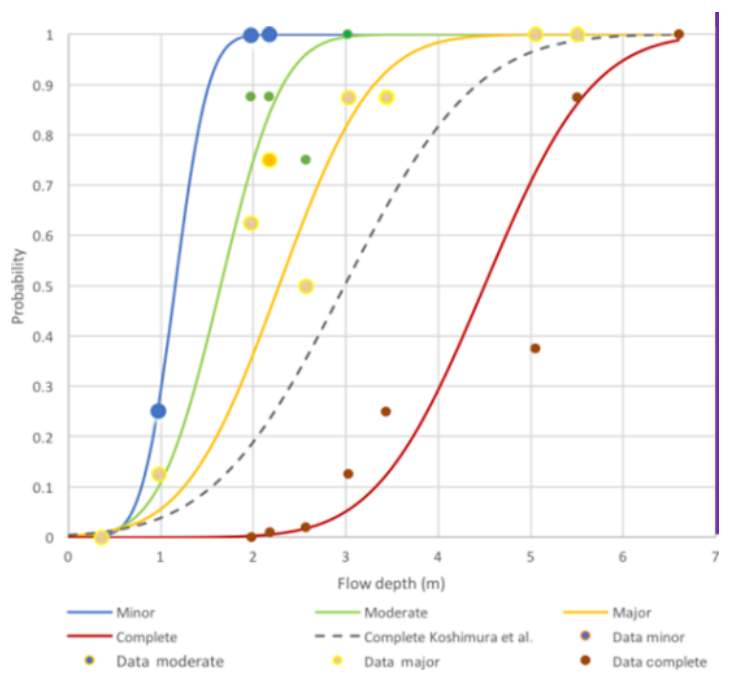

Fig. 21. Identification of the possibility of finding a tsunami for SDN 48 and SDN 08

As can be seen in Fig. 21 above that 2004 tsunami records in SDN 48' and SDN 8' buildings, which are located in Meuraxa and Kuta Raja Districts, reached 7 meters. According to vulnerability curve [9], the damage states probability for those buildings are $100 \%$. Hence, the tsunami hit those buildings and caused total damage. As a result, the tsunami's hit left solely basement.

\section{Conclusions and suggestions}

\subsection{Conclusions}

Based on the results of the discussion and data analysis carried out, a conclusion is drawn regarding the study of the vulnerability of school buildings with reinforced concrete construction in Banda Aceh City to earthquake and tsunami hazards as follows:

1. Based on the results of structural behavior due to Sumatera-Andaman earthquake 2004 and indonesia seismic hazards map 2017 earthquake source map at SDN 48 and SDN 8, the value of inter story drift is greater than the inter story drift permit levels, then the building does not meet the provisions of SNI 1726-2019

2. Based on the results of structural behavior due to the 2004 tsunami load at SDN 48 and SDN 8, inter story drift in the y direction is greater than permits because the height of inundation at that location reaches the second floor.

3. From the results of the spectrum response Puskim program, the spectrum acceleration (Sa) for SDN 48 buildings is $1,000124 \mathrm{~g}$ and SDN 8 is 1.001245 g.

4. From the results of determining the level of damage states on the capacity spectrum curve with $\mathrm{Sa}$ values of 1,000124 and 1.001245 for SDN 48 and SDN 8 buildings, it was found that the school buildings are in a yielding position towards the level of light damage, while based on the seismic fragility curve that has been developed probability for slight damage is $100 \%$ and moderate damage reaches $90 \%$.

5. Based on the tsunami fragility curve that has been developed with a tsunami height of 7 meters in SDN 48 and SDN 8, the probability value for each level of damage is $100 \%$, in other words, the probability will be complate damage.

\subsection{Sugesstions}

From this research, several suggestions and inputs related to research can be obtained so that further research or development can be carried out, namely:

1. Using the structural data of the building itself such as detailed drawings, column compressive strength test results and steel tensile test results in order to create a more accurate seismic fragility curve.

2. Calculate earthquake modeling according to the location of the school building and the source of the earthquake.

3. Create a tsunami fragility curve based on the capacity of school buildings.

4. Make a building model without walls to see the behavior of the building due to the tsunami load.

\section{References}

1. Sugiyanto, D., Zulfakriza, Ismail, N., Adriansyah, F., Meilano, I., dan Hasanuddin, Z.A. (2011). Analisa Deformasi Permukaan Patahan Aktif Segmen Seulimum dan Segmen Aceh. Dipresentasikan pada Prosiding Seminar Hasil Penelitian Kebencanaan TDMRC-Unsyiah, Banda Aceh, 13 - 19 April 2011.

2. HAZUS (Hazard US), (1999): Earthquake Loss Estimation, National Institute of Building Sciences. NIBS: Washington D.C.

3. Badan Standarisasi Nasional. (2019). Standar Nasional Indonesia 1726-2019: Tata Cara Perencanaan Ketahanan Gempa untuk Struktur Bangunan Gedung dan non Gedung. Badan Standarisasi Nasional: Jakarta.

4. Sugito, N. T. (2008). Tsunami, Universitas Pendidikan Indonesia, Bandung.

5. Utomo, C., Susanto, R., Tudjono, S., \& Wibowo, H. (2012). Evaluasi Struktur Dengan Pushover Analysis pada Gedung Kalibata Residences Jakarta. Jurnal Karya Teknik Sipil, 1(1), 1-10

6. Wibowo, N. A. (2016). Pengembangan Kurva Kerapuhan Berbasis Incremental Dynamic Analysis untuk Evaluasi Kinerja Seismik Jembatan Beton. Tugas Sarjana, Teknik Sipil Universitas Sebelas Maret: Surakarta.

7. Gentile, R., Galasso, C., Idris, Y., Rusydy, I., dan Meilianda, E. (2019). From Rapid Visual Survey to Multi-Hazard Risk Prioritisation and Numerical Fragility of School Buildings, Nat. Hazards Earth Syst. Sci., 19, 1365-1386. 
8. Koshimura, S., Namegaya, Y., Yanagisawa, H. (2009). Tsunami Fragility A New Measure to Identify Tsunami Damage, Jurnal of Disaster Research Vol.4 No.6, Japan.

9. Syamsidik, Benazir, Lutfi, M., Suppasri, A., dan Comfort, L. K. (2020). The 22 December 2018 Mount Anak Krakatau volcanogenic tsunami on Sunda Strait coasts, Indonesia: tsunami and damage characteristics, NHESS, 20(2), 549-565.

10. Iemura, H., Pradono, M. H., Sugimoto, M., Takahashi, Y., dan Husen, A. (2012). Tsunami Height Memorial Poles In Banda Aceh And Recommendations For Disaster Prevention, Proceedings of the International Symposium on Engineering Lessons Learned from the 2011 Great East Japan Earthquake, Tokyo, Japan, March 1-4.

11. Duan, X., Pappin, JW. (2008). A Procedure for Establishing Fragility Functions for Seismic Loss Estimate of Existing Buildings Based on Nonliner Pushover Analysis, dipresentasikan pada The 14th World Conference on Earthquake Engineering, Beijing, 12-17 Oktober.

12. Badan Standarisasi Nasional. (2020). Standar Nasional Indonesia 1727-2020: Beban Desain Minimum dan Kriteria Terkait untuk Bangunan Gedung dan Struktur Lain. Badan Standarisasi Nasional: Jakarta.

13. Federal Emergency Management Agency. (2019). Guidelines for Design of Structures for Vertical Evacuation from Tsunami Third Edition. Department of Homeland Security FEMA Mitigation Division: Washington D.C. 